\title{
Service Quality and Students Level of Satisfaction in Private Colleges in Vietnam
}

\author{
Hung Van Truong ${ }^{1}$, Cuong Hung Pham ${ }^{2} \&$ Nhan Hoang $\mathrm{Vo}^{3}$ \\ ${ }^{1}$ Duc Tri College, Vietnam \\ ${ }^{2}$ Foreign Trade University, Ho Chi Minh City Campus, Vietnam \\ ${ }^{3}$ University of Medicine Pham Ngoc Thach, Vietnam \\ Correspondence: Nhan Hoang Vo, University of Medicine Pham Ngoc Thach, \#86/2 Thanh Thai, District 10, Ho Chi \\ Minh City, Vietnam.
}

Received: April 9, 2016

Accepted: May 4, 2016

Online Published: May 13, 2016

doi:10.5430/ijfr.v7n3p121

URL: http://dx.doi.org/10.5430/ijfr.v7n3p121

\begin{abstract}
The study of service quality and students level of satisfaction in selected private colleges in Vietnam conducted during the period from April 2013 to December2015. The research result showed that there were 500 students (463 processed and 37 missed) who to be interviewed and answered nearly 24 questions. The researcher had analyzed $\mathrm{KMO}$ test, the result of KMO analysis used for multiple regression analysis. The student responses measured through an adapted questionnaire on a 5-point Likert scale. Hard copy and interviewstudent by questionnaire distributed among students of the private colleges in Vietnam. The regression analysis results showed that there were five factors, which included of factors following: Tangibility; Guarantee; Reliability; Responses and Empathyactually affected students' satisfaction with $5 \%$ significance level. The main objectives of this study were following:

- to find factors that affecting the students' satisfactionof the private colleges in Vietnam.

- to identify some factors that affected on the students' satisfaction of the private colleges in Vietnam.

- to analyze and to test some factors that affected the students' satisfaction of the private colleges in Vietnam.

Keywords: service quality, student satisfaction, private colleges, Vietnam

\section{Introduction}

In Vietnam, the 2010-2011 school year, there were 413 universities and colleges, 2.27 million students, the unemployment rate has reached 40\% of trained, "Education Development Strategy 2011-2020" to 2020, there will be 900 universities and colleges with a total of 4.5 million students, the percentage of workers through vocational training and universities reached $70 \%$ (doubling in 10 years). When the economy opens towards a market economy, the education sector is also regarded as a service. The school autonomic ally provides educational services for learners and learners are considered as customer or as users of educational services. Therefore, the school must create, innovate to improve quality.

Nowadays, education is considered as a service, which is an important source of revenue for many countries with developing economies. Therefore, the competition among educational institutions to attract foreign and domestic students becomes more and more competitive. Dr. Tom Verhoeff (1997) suggests that education and competition are two global entities, in which education plays a huge role and profound impact on people's lives. There are many different components of society to invest in education and so many people have benefits more than just state investment in education. Do not have a monopoly in the business of educational products (books, textbooks, equipment ...). There is the Impact of the law of supply and demand in education. Families and students have the right to choose schools. Combined with the practical requirements of the teaching job, the researchers has chosen service quality and students level of satisfaction in private colleges in Vietnam for study.
\end{abstract}

\section{Literature Review}

Parasuraman et al. (1985) suggested SERVQUAL as a determinants and measuring instrument of service quality. It considered as a good starting point for providing more detail to a description of service quality. They defined "determinants of service quality as a measure of how well the service level delivered matches customer expectations". They designed SERVQUAL based on studies in America. They described ten determinants of service quality as reliability, responsiveness, competence, access, courtesy, communication, credibility, security, understanding the customers and tangibles. 
Later, Parasuraman et al. (1988) reduced the ten attributes to five attributes. The model of changed SERVQUAL was reliability, responsiveness, assurance, empathy and tangibles.

Firdaus developed HEdPERF model by comparing with SERVPERF (HEdPERF-SERVPERF) in order to access the relative advantages and disadvantages of each instrument, to identify the most superior instrument. SERVPERF is another service quality-measuring instrument developed by Cronin \& Taylor (1992). Cronin \& Taylor criticized the framework of SERVQUAL and developed their own model "SERVPERF", consisting of 22 items, and kept only the perception of service quality. Fridaus categorized five determinants of service quality in higher education. They are non-academic aspect, academic aspect, reputation, access and program issues.

The concept of quality has evolved from "excellence" to "value", to "conformance to specification" and to "meeting and exceeding customer expectations" (Reeves \& Bendnar, 1994). The first two definitions of quality are quite similar in that they both have common views on assessing and measuring the quality of both products or services, whereas the third is more appropriate for assessing only the quality of products (Pariseau \& McDaniel, 1997).

Service quality may be conceptualized as customers or consumers overall feeling about the superiority or inferiority of the services they received from the service provider (Zeithaml et al., 1990). The most commonly referred to definition of service quality is the difference between customer expectations of what a customer will receive from a service provider and the perceptions about the services received by customer from the service provider.

Quality, performance and satisfaction are considered to be the key factors and these factors are interrelated in a causal relationship or some time these three factors are used as synonymously due to the similarity in meaning (Cronin et al., 2000; Bitner and Hubert, 1994). Still there is no precise definition of service quality from an educational point of view.However, according to O'Neill and Palmer (2004, p: 42), service quality in education can be defined as "the difference between what a student expects to receive and his/her perceptions of actual delivery" (cited in A. Ijaz, S.M. Irfan, S. Shahbaz, M. Awan, M. Sabir, 2011).The measurement parse concept of quality services into five elements:

- Tangibility: Facilities, equipment, appearance of staff....

- Reliability: The ability to do services on time and fit right at the first time.

- Responsiveness: Being ready to help and respond to customer's need.

- Assurance: Employee's ability to get customer's trust.

- Empathy: Demonstrate the care to each client.

In this framework, the students' satisfactionof the private collegesisthe dependent variablebutTangibility; Guarantee; Reliability; Responses and Empathythat are independent variables.

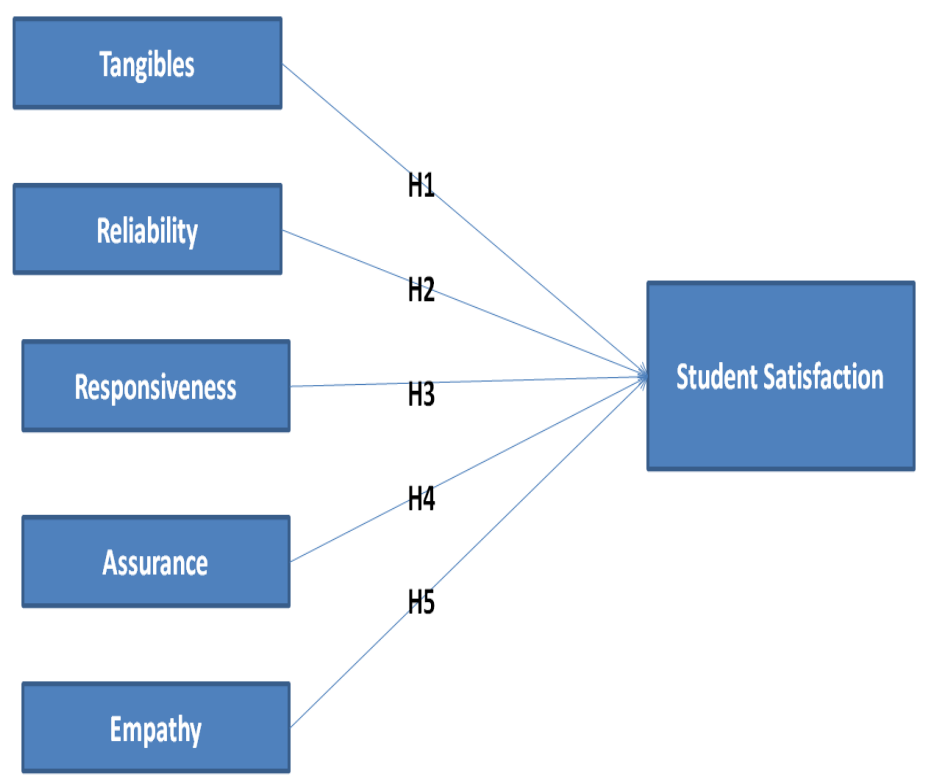

Figure 1. Research model for the students' satisfaction of the private colleges 
Based on the aforementioned research questions the following hypotheses used to investigate each question:

$\mathrm{H}_{1}$ : There is a positive relationship between Tangibles and the students' satisfaction of the private colleges.

$\mathrm{H}_{2}$ : There is a positive relationship between Reliability and the students' satisfaction of the private colleges.

$\mathrm{H}_{3}$ : There is a positive relationship between Responsiveness and the students' satisfaction of the private colleges.

$\mathrm{H}_{4}$ : There is a positive relationship between Guarantee (assurance) and the students' satisfaction of the private colleges.

$\mathrm{H}_{5}$ : There is a positive relationship between Empathy and the students' satisfaction of the private colleges.

\section{Research Method}

The preliminary study for students conducted in 10/2013, using qualitative methods to interview 30 students of the CPD and CDAto examine the content and meaning of the words used in the scale. Following this, the formal study conducted in May 2014, using qualitative methods to interview 500 students to examine the content and meaning of the words used in the scale.

The population of this study was all students of the CPD and CDA (4.000 students) that the values of the random variable of interest could possibly be determined. This notion corresponds directly to the frame in sample survey literature. The difference between the attributes of interest in the study population and the corresponding attributes in the target population called the study error. This is a simple quantitative assessment for numerical attributes but can be challenging to define for graphical ones.

After preliminary investigations, formal research done by using quantitative methods questionnaire survey of 500 students of the CPD and CDA who related and 30 educational managers. The reason tested measurement models, model and test research hypotheses. Data collected were tested by the reliability index (excluding variables with correlation coefficients lower $<0.30$ and variable coefficient Cronbach's alpha $<0.60$ ), factor analysis explored (remove the variable low load factor $<0.50$ ). The hypothesis tested through multiple regression analysis with linear Enter method. The observed data was calculated by minimizing the sum of the squares of the vertical deviations from each data point to the line (if a point lies on the fitted line exactly, then its vertical deviation is 0 ). Because the deviations are first squared, then summed, there are no cancellations between positive and negative values. The least-squares estimates $b_{0}, b_{1} \ldots b_{n}$ are usually computed by statistical software. Regression:

$$
\begin{aligned}
& \mathrm{Y}=\beta_{0}+\beta_{1} X_{1}+\beta_{2} X_{2}+\beta_{3} \mathrm{X}_{3}+\beta_{4} \mathrm{X}_{4}+\beta_{5} X_{5} \\
& \mathrm{Y} \text { : The students' satisfaction of the } \mathrm{CPD} \text { and CDA } \\
& \mathrm{X}_{1} \text { : Responsiveness; } \\
& \mathrm{X}_{2} \text { : Tangibles; } \\
& \mathrm{X}_{3} \text { : Reliability; } \\
& \mathrm{X}_{4} \text { : Guarantee and } \\
& \mathrm{X}_{5} \text { : Empathy }
\end{aligned}
$$

In this research, the confident level is $95 \%$ (Significance $=0.05$, t-test) for confidence interval.

\section{Research Results}

Table 1. Descriptive statistics for the service quality

\begin{tabular}{cccccc}
\hline Code & $\mathrm{N}$ & Minimum & Maximum & Mean & Std. Deviation \\
\hline RES1 & 463 & 1 & 5 & 3.31 & .892 \\
RES2 & 463 & 1 & 5 & 3.30 & .889 \\
RES3 & 463 & 1 & 5 & 3.27 & .969 \\
RES4 & 463 & 1 & 5 & 3.25 & .934 \\
RES5 & 463 & 1 & 5 & 3.55 & .957 \\
RES6 & 463 & 1 & 5 & 3.16 & .935 \\
TAN1 & 463 & 2 & 5 & 3.68 & 1.293 \\
TAN2 & 463 & 2 & 5 & 3.58 & 1.190 \\
TAN3 & 463 & 1 & 5 & 3.39 & 1.332
\end{tabular}




\begin{tabular}{cccccc} 
TAN4 & 463 & 1 & 5 & 3.56 & 1.213 \\
GUA1 & 463 & 1 & 5 & 3.19 & 1.094 \\
GUA2 & 463 & 1 & 5 & 3.17 & 1.226 \\
GUA3 & 463 & 1 & 5 & 3.13 & 1.041 \\
GUA4 & 463 & 1 & 5 & 3.44 & 1.252 \\
REL1 & 463 & 1 & 5 & 3.35 & 1.004 \\
REL2 & 463 & 1 & 5 & 3.34 & .998 \\
REL3 & 463 & 1 & 5 & 3.35 & .934 \\
REL4 & 463 & 1 & 5 & 3.08 & .947 \\
EMP1 & 463 & 2 & 5 & 3.42 & 1.291 \\
EMP2 & 463 & 1 & 5 & 2.97 & .872 \\
EMP3 & 463 & 1 & 5 & 2.83 & 1.449 \\
SAT1 & 463 & 2 & 5 & 3.33 & .655 \\
SAT2 & 463 & 2 & 5 & 3.29 & .734 \\
SAT3 & 463 & 2 & 5 & 3.42 & .675 \\
Valid N (listwise) & 463 & & & & \\
\hline
\end{tabular}

Source: The researcher's collecting data and SPSS

Table 3 showed that there were 500 students of CPD and CDA interviewed from 10/2014 to 6/2015. There were 463 students processed. The results showed that max value is 5 , minimum is 1 , mean is around 3.0 and Std. Deviation is around 1.0.

Table 2. Results of analysis of Cronbach Alpha coefficients

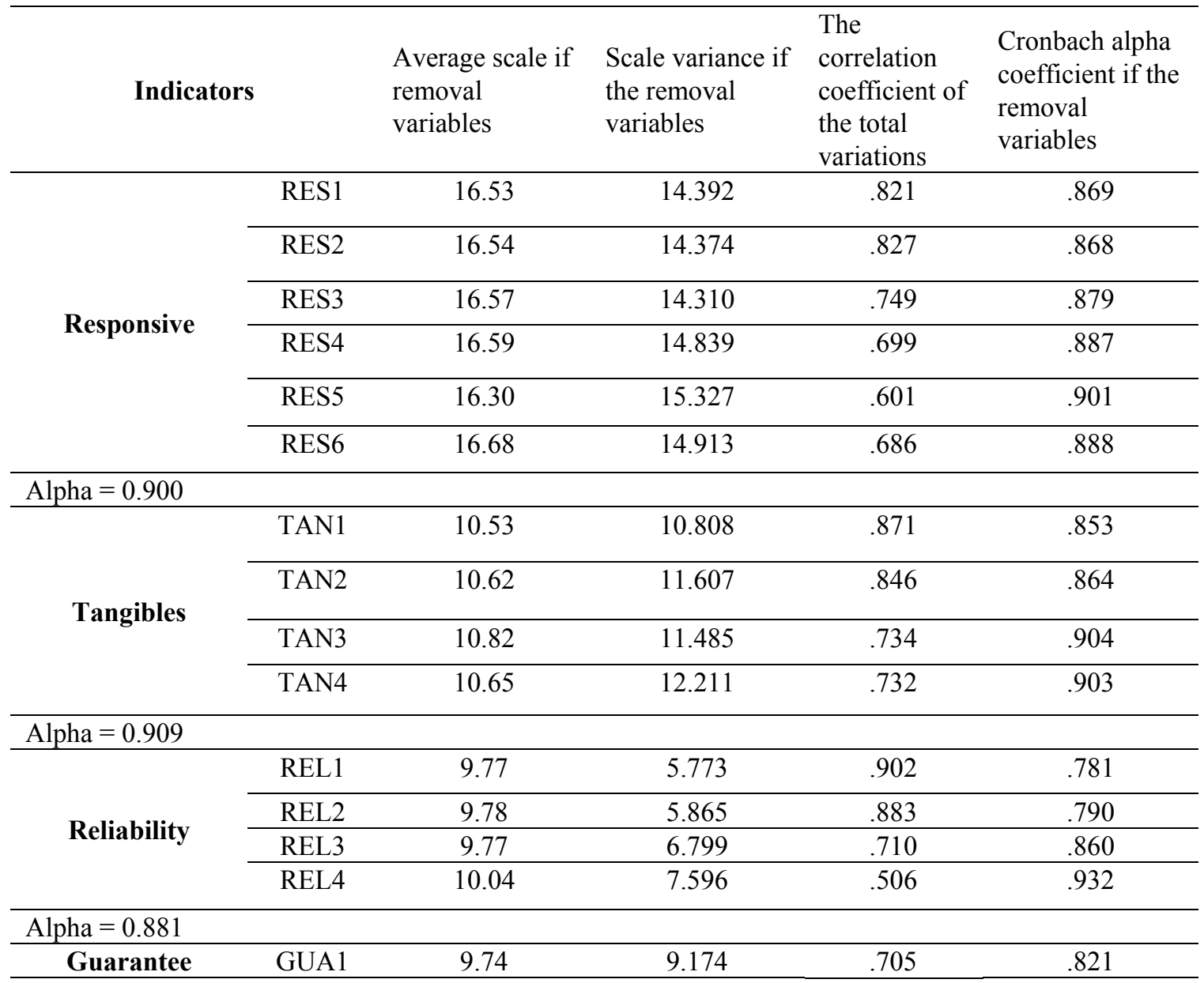




\begin{tabular}{cccccc}
\hline & GUA2 & 9.77 & 8.140 & .772 & .791 \\
\cline { 2 - 6 } & GUA3 & 9.80 & 9.805 & .637 & .847 \\
\hline Alpha $=0.859$ & & & & & \\
\hline \multirow{2}{*}{ Empathy } & EMP1 & 5.79 & 4.116 & .457 & .611 \\
\cline { 2 - 6 } & EMP2 & 6.25 & 5.290 & .530 & .576 \\
\cline { 2 - 6 } & EMP3 & 6.38 & 3.297 & .528 & .527 \\
\hline Alpha $=0.931$ & & & & & \\
\hline
\end{tabular}

Source: The researcher's collecting data and SPSS

The Table 2 revealed that all of components are very good for this research. Continue author analyzed the EFA to assess more accurately the scale, helping the uniform scale in research. Thus, based on the authors EFA analysis will evaluate the homogeneity of the observed variables and can be classified because of specific variables. Besides, Cronbach alpha coefficient if the removal variables is more than 0.6. In addition, the correlation coefficient of the total variations is more than 0.3 .

KMO \& Bartlett's Test of Sphericity is a measure of sampling adequacy that recommended checking the case to variable ratio for the analysis conducted. In most academic and business studies, KMO \& Bartlett's test play an important role for accepting the sample adequacy. While the KMO ranges from 0 to 1 , the world-over accepted index is over 0.6. In addition, the Bartlett's Test of Sphericity relates to the significance of the study and thereby shows the validity and suitability of the responses collected to the problem addressed through the study. For Factor Analysis recommended suitable, the Bartlett's Test of Sphericity must be less than 0.05 .

Table 3. KMO and Bartlett's Test for factors affecting the students' satisfaction

\begin{tabular}{llc}
\hline Kaiser-Meyer-Olkin Measure of Sampling Adequacy. & .795 \\
& Approx. Chi-Square & 7722.151 \\
Bartlett's Test of Sphericity & Df & 210 \\
& Sig. & .000 \\
\hline
\end{tabular}

Total Variance Explained

\begin{tabular}{cccccccc}
\hline Com. & \multicolumn{3}{c}{ Initial Eigenvalues } & \multicolumn{3}{c}{ Extraction Sums of Squared Loadings } & $\begin{array}{c}\text { Rotation Sums of } \\
\text { Squared } \\
\text { Loadings }\end{array}$ \\
\cline { 2 - 8 } & Total & $\begin{array}{c}\text { \% of } \\
\text { Variance }\end{array}$ & $\begin{array}{c}\text { Cumulative } \\
\text { \% }\end{array}$ & Total & $\begin{array}{c}\text { \% of } \\
\text { Variance }\end{array}$ & $\begin{array}{c}\text { Cumulative } \\
\%\end{array}$ & Total \\
\hline 1 & 5.583 & 26.584 & 26.584 & 5.583 & 26.584 & 26.584 & 4.988 \\
2 & 3.724 & 17.734 & 44.317 & 3.724 & 17.734 & 44.317 & 3.331 \\
3 & 2.593 & 12.350 & 56.667 & 2.593 & 12.350 & 56.667 & 4.187 \\
4 & 1.654 & 7.874 & 64.541 & 1.654 & 7.874 & 64.541 & 3.076 \\
5 & 1.458 & 6.945 & 71.486 & 1.458 & 6.945 & 71.486 & 2.163 \\
6 & .801 & 3.813 & 75.299 & & & & \\
7 & .710 & 3.380 & 78.679 & & & & \\
8 & .677 & 3.222 & 81.901 & & & & \\
9 & .616 & 2.932 & 84.834 & & & & \\
10 & .571 & 2.721 & 87.555 & & & & \\
11 & .482 & 2.293 & 89.848 & & & & \\
12 & .444 & 2.114 & 91.962 & & & & \\
13 & .341 & 1.622 & 93.584 & & & & \\
14 & .300 & 1.427 & 95.011 & & & & \\
\end{tabular}




$\begin{array}{cccc}15 & .260 & 1.240 & 96.252 \\ 16 & .246 & 1.172 & 97.423 \\ 17 & .202 & .963 & 98.386 \\ 18 & .181 & .860 & 99.246 \\ 19 & .119 & .564 & 99.810 \\ 20 & .023 & .110 & 99.920 \\ 21 & .017 & .080 & 100.000\end{array}$

Source: The researcher's collecting data and SPSS

Table 3 showed that Kaiser-Meyer-Olkin Measure of Sampling Adequacy was statistically significant and high data reliability $(\mathrm{KMO}=0.795>0.6)$. This result was very good for data analysis. Table 4 showed that Cumulative percent was statistically significant and high data reliability was $71.486 \%$ (> $60 \%)$.

Table 4. Structure Matrix for factors of the students' satisfaction

\begin{tabular}{|c|c|c|c|c|c|}
\hline \multirow[t]{2}{*}{ Code } & \multicolumn{5}{|c|}{ Component } \\
\hline & 1 & 2 & 3 & 4 & 5 \\
\hline RES1 & .887 & & & & \\
\hline RES2 & .877 & & & & \\
\hline RES3 & .863 & & & & \\
\hline RES4 & .829 & & & & \\
\hline RES6 & .725 & & & & \\
\hline RES5 & .683 & & & & \\
\hline TAN1 & & .931 & & & \\
\hline TAN2 & & .920 & & & \\
\hline TAN4 & & .850 & & & \\
\hline TAN3 & & .842 & & & \\
\hline REL2 & & & .968 & & \\
\hline REL1 & & & .961 & & \\
\hline REL3 & & & .765 & & \\
\hline REL4 & & & .672 & & \\
\hline GUA2 & & & & .889 & \\
\hline GUA1 & & & & .848 & \\
\hline GUA4 & & & & .835 & \\
\hline GUA3 & & & & .783 & \\
\hline EMP1 & & & & & .792 \\
\hline EMP2 & & & & & .786 \\
\hline EMP3 & & & & & .768 \\
\hline
\end{tabular}

Source: The researcher's collecting data and SPSS

Table 4 showed that Structure Matrix for the Factors affecting the students' satisfaction had 5 Components. Component 1 was Responsiveness (X1), Component 2 was Tangibles (X2), Component 3 was Reliability (X3), Component 4 is Guarantee (X4) andComponent 5was Empathy (X5) for affecting the students' satisfaction.

Table 5. KMO and Bartlett's Test for the students' satisfaction

\begin{tabular}{llc}
\hline \multicolumn{2}{l}{ Kaiser-Meyer-Olkin Measure of Sampling Adequacy. } & .664 \\
\hline \multirow{3}{*}{ Bartlett's Test of Sphericity } & Approx. Chi-Square & 273.453 \\
\cline { 2 - 3 } & df & 3 \\
\cline { 2 - 3 } & Sig. & .000 \\
\hline
\end{tabular}

Source: The researcher's collecting data and SPSS 
Table 5 showed that KMO and Bartlett's Test for the students' satisfaction showed that Kaiser-Meyer-Olkin Measure of Sampling Adequacy was statistically significantandhigh datareliability $(\mathrm{KMO}=0.664>0.6)$. This result was very good for data analysis. The students' satisfaction showed that Cumulative percent was statistically significantandhigh datareliabilitywas $63.805 \%$ (> $60 \%$ ).

Table 6. KMO and Bartlett's Test for factors affecting the students' satisfaction

\begin{tabular}{|c|c|c|}
\hline & Indicators & KMO and Bartlett's Test \\
\hline \multirow{5}{*}{ FACTORS } & Responsiveness & 0.814 \\
\hline & Tangibles & 0.762 \\
\hline & Reliability & 0.731 \\
\hline & Guarantee & 0.748 \\
\hline & Empathy & 0.660 \\
\hline
\end{tabular}

Source: The researcher's collecting data and SPSS

This result was very good for data analysis. The students' satisfaction showed that Cumulative percent was statistically significant and high data reliability and KMO and Bartlett's Test was over 0.60 .

\section{Conclusion}

The importance of measuring student satisfaction with private college services has evolved beyond theoretical discussion. The consequences of increased competition among higher education institutions, diminished state funding, mounting attention by governing bodies on institutional accountability, and changes in student body demographics have all contributed to an atmosphere of growing private inquiry of institutions of higher education.

Besides, students' satisfaction is a feeling of happiness or pleasure because you have achieved something or got what you wanted. This study wants to identify students' overall satisfaction with the key features with the private colleges; student perceptions, teaching quality, enrolment, learning environment, learning systems, research facilities. The results from data analysis revealed that respondents consider the followingfactors as the most influential factors:

- Tangibles; Standardized Coefficients of Beta is 0.413 .

- Empathy; Standardized Coefficients of Beta is 0.396.

- Responsiveness; Standardized Coefficients of Beta is 0.392.

- Reliability; Standardized Coefficients of Beta is 0.159.

- Guarantee; Standardized Coefficients of Beta is 0.156 .

All five most influential factors related to the students' satisfaction of the private collegeswith significance level of $5 \%$. This result confirmed what found in the tangiblesthat was the most important factor to the students' satisfaction of the private colleges.

All five most influential factors related to the students' satisfaction of the private colleges with significance level of $5 \%$. This result confirmed what found the guaranteethat was the less important factor to the students' satisfaction of the private colleges.

After the analysis of the survey of all the collected data, we can conclude that theseservice quality variables have significant relationships with the overall satisfaction of thestudents who were studying atthe private colleges. The service qualityvariables and student satisfaction have a moderately positive correlation that meansthere is still room for continuous improvement.

\section{References}

Ahrens, L., \& Kemmerer, F. (2002). Higher education development. CambodiaDevelopment Review.

Altbach, P. (Ed.). (1999). Private Prometheus: Private higher education and developmentin the 21st century. Westport, Conn. Greenwood Press.

Ansell, T. (1993). Managing for quality in the financial services industry. London: Chapman \& Hall.

Ari Warokka. (2011). Service Quality and Students' Satisfaction at Higher Learning Institutions: The Competing Dimensions of Malaysian Universities' Competitiveness. Journal of Southeast Asian Research. 
Ato. GebreSorsaTakaro. (2014). Measuring Service Quality and Students' Satisfaction-A Case Study on Hawassa University. SPC ERA International Journal of Business and Management.

Becket, N., \& Brookes, M. (2006). Evaluating quality management in university departments. Quality Assurance in Education.

Bell, J. E. (1989). Projective Techniques: A. Dynamic Approach to the Study of Personality. New York: Longmans.

Best, John W., \& Kahn, James V. (1986). Research in Education (5th ed.). New Delhi: Prentice-Hall of India.

Biggs, J. (1995). Teaching for better learning. Classroom Learning: Educational Psychology for the Asian Teachers. Singapore: Prentice Hall.

Chapman, D. W. (1981). A model of student college choice. The Journal of Higher Education.

D. Patrick Saxon. (2014). Student Satisfaction and Academic Performance in Armenian Higher Education. American International Journal of Contemporary Research.

Fosnot, C. T. (1996). Constructivism: Theory, perspectives, and practice. New York, NY: Teachers College Press.

Gruber. (2001). Examining Student Satisfaction with Higher Education Services Using a New Measurement Tool. Institute for Educational Science Jena, Germany.

Harvey, L., \& Green, D. (1993). Assessment and Evaluation in Higher Education.

Hishamuddin Fitri Abu Hasan. (2008). Service Quality and Student Satisfaction: A Case Study at Private Higher Education Institutions. International Business Research.

Ilias, A., Hasan, H. F. A., Rahman, R. A., \& Yasoa, M. R. (2008). Student Satisfaction and Service Quality: Any Differences in Demographic Factors? International Business Research.

Kallio R. E. (1995). Factors Influencing the College Choice Decisions of Graduate Students. Research in Higher Education.

Karen Swan. (2001). Design factors affecting student satisfaction and perceived learning in Asynchronous Online Courses. International Journal of Humanities and Social Science.

Karen Swan. (2001). Vitrual interactivity: design factors affecting student satisfaction and perceived learning in Asynchronous Online Courses. International Journal of Humanities and Social Science.

Kusumawati, A. (2013). A Qualitative Study of the Factors Influencing StudentChoice: The Case of Public University in Indonesia. Journal of Basic and Applied Scientific Research.

Lokman Coskun. (2014). Investigating the Essential Factors on Student Satisfaction: A Case of Albanian Private University. Journal of Educational and Social Research.

Marvin J. Burns. (2006). Factors influencing the college choice of africanamerican students admitted to the college of agriculture, food and natural resources. A Thesis presented to the Faculty of the Graduate School.University of Missouri, USA.

MuhammedEhsan Malik. (2010). The Impact of Service Quality on Students' Satisfaction in Higher Education Institutes of Punjab. Journal of Management Research.

Perna, L., \& Titus, M. (2004). Understanding Differences in the Choice of College Attended: The Role of State Public Policies. The Review of Higher Education.

Song, C., \& E. Glick, J. (2004). College Attendance and Choice of College Majors Among Asian-American Students. Social Science Quarterly.

Suleiman Al Khattab. (2006). Assessing students' satisfaction with quality of service of students information system. Journal of Research in Business and Management.

Tarik Hossain. (2012). Students' Satisfaction: A Study among Private University Students of Bangladesh. World Journal of Social Sciences.

Usman, A. (2010). The Impact of Service Quality on Students' Satisfaction in Higher Education Institutes of Punjab. Journal of Management Research.

Watkins, A. E., Richard L. Scheaffer, \& George W. Cobb. (2008). Statistics in action: understanding a world of data. Emeryville, CA: Key Curriculum Press.

Yi-Ju Chen. (2007). Effects of Online Interaction on Adult Students' Satisfaction and Learning. The Journal of Human Resource and Adult Learning.

Yousef Mehdipour. (2013). Student satisfaction at Osmania University. International Journal of Advancements in Research \& Technology. 